\title{
Antinociceptive effect of methanol extract of Dalbergia sissoo leaves in mice
}

\author{
Md. Abdul Mannan ${ }^{*}$, Ambia Khatun and Md. Farhad Hossen Khan
}

\begin{abstract}
Background: Dalbergia sissoo DC. (Family: Fabaceae) is a medium to large deciduous tree, is locally called "shishu" in Bangladesh. It is used to treat sore throats, dysentery, syphilis, bronchitis, inflammations, infections, hernia, skin diseases, and gonorrhea. This study evaluated the antinociceptive effect of the methanol extract of $D$. sissoo leaves (MEDS) in mice.

Methods: The extract was assessed for antinociceptive activity using chemical and heat induced pain models such as hot plate, tail immersion, acetic acid-induced writhing, formalin, glutamate, and cinnamaldehyde test models in mice at the doses of 100, 200, and $400 \mathrm{mg} / \mathrm{kg}$ (p.o.) respectively. Morphine sulphate (5 mg/kg, i.p.) and diclofenac sodium (10 mg/kg, i.p.) were used as reference analgesic drugs. To confirm the possible involvement of opioid receptor in the central antinociceptive effect of MEDS, naloxone was used to antagonize the effect.

Results: MEDS demonstrated potent and dose-dependent antinociceptive activity in all the chemical and heat induced mice models $(p<0.001)$. The findings of this study indicate that the involvement of both peripheral and central antinociceptive mechanisms. The use of naloxone verified the association of opioid receptors in the central antinociceptive effect.
\end{abstract}

Conclusions: This study indicated the peripheral and central antinociceptive activity of the leaves of D. sissoo. These results support the traditional use of this plant in different painful conditions.

Keywords: Dalbergia sissoo, Antinociceptive, Opioid receptors

\section{Background}

Dalbergia sissoo DC. (Family: Fabaceae) is a medium to large deciduous tree, is commonly known as sisu, sheesham, tahli, tali, jag at different parts of the world and is locally called "shishu" in Bangladesh. It is usually used to treat sore throats, dysentery, syphilis, and gonorrhoea [1]. It is used in conditions like blood purifier, leprosy, headaches, bronchitis, inflammations, infections, hernia, and skin diseases [2]. It has been also reported to use as stimulant, astringent [3]; colorectal cancer and bacterial infections [4]. Juice of the leaves is useful for anthelmintic, eye and nose diseases. It also used in scabies, burning sensation, scalding urine and digestive disorders [5-8]. It is used as expectorant, anti-emetic, leucoderma, ulcers, and gout like medicinal properties [9]. Boiled leaf

\footnotetext{
* Correspondence: manna.034@gmail.com

Department of Pharmacy, Stamford University Bangladesh, 51, Siddeswari Road, Dhaka 1217, Bangladesh
}

filtrate is used to wash hair for removing dandruff and or long hair [10].

Isoflavones, biochanin-A, muningin, sissotrin, amyrin, stigmasterol have been isolated from the aerial parts of Dalbergia sissoo Roxb [11]. The stem-bark has been reported to contain dalberjenone, dalbergin and methyl dalbergin and a new 4-phenyl chromene, dalbergichromene [12]. The mature pods contain a new isoflavone glucoside identified as caviunin 7-0-gentiobioside [13] isoflavone diglucoside recognize as isocaviunin 7 gentiobioside [14]. The root bark of Dalbergia sissoo contain a chalcone, 2, 3- dimethoxy-40-g, g-

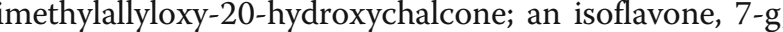
g-dimethylallyloxy- 5-hydroxy-40-methoxyisoflavone; a fivone, 7-hydroxy-6-methoxyflavon; a isoflavone, bioRhamnose, ga lated from the leave [16]. Compounds obtained from Dalbergia sissoo like an isoflavone, biochanin is a potent 
chemotherapeutic cancer preventive agent with a distinct estrogenic activity has been isolated from the fresh flowers of Dalbergia sissoo. Two rare glycosides such as kaempferol and quercetin rutinosides were isolated in a low yield from the flowers of Dalbergia sissoo [17, 18].

Pharmacological studies have evaluated the analgesic and anti-pyretic [19], anti-diabetic [20], anti-inflammatory [21] and anti-diarrheal effect of the extract [22]. The plant bark has been reported the anti-nociceptive [23], antioxidant [24] and anti-spermatogenic activity [25]. The oil extracted from wood scrapings of Dalbergia sissoo has shown dose dependent larvicidal activity against mosquitoes [26]. Anti-osteogenic activity has also been performed this crude extract of Dalbergia sissoo [27]. The plant extract has been used as an alternative to synthetic pesticides for termite control in buildings [28]. The seeds extract has modest analgesic and notable anti-pyretic activities [29]. The ethanolic extract of the bark of Dalbergia sissoo Roxb. was investigated for its activity against helminthic infections [30]. In the search for the molluscicidal activity, the plant extracts were evaluated against egg masses and adults of Biomphalaria pfeifferi and the snail intermediate host of Schistosoma manson in Nigeria [31]. In-vivo, intrastriatal injection of mitochondrial toxin in rats produce excitotoxic lesions, while chronic administration of 3-NP produces excitotoxic-like lesions regionally restricted to striatum in both rats and non-human primates [32]. It prevents central nervous system damage [33].

According to the previous study, leaves and barks of D. sissoo presented the antinociceptive properties $[19,23]$. Based on the studies, we designed and conducted the present work to assess the effect of methanol extract of $D$. sissoo leaves with six pain models in mice and two mechanism of action study for possible activity. The present research also warrants further investigation into the complex mechanism of action of methanol extract of $D$. sissoo leaves on induced antinociception.

\section{Methods}

\section{Plant material and extraction}

The fresh leaves of $D$. sissoo were collected from Khanpur, Bogra, Bangladesh in the month of June 2015. The plant samples were then identified and authenticated by Sarder Nasir Uddin, Senior Scientific Officer, Bangladesh National Herbarium, Dhaka, Bangladesh. A voucher specimen number (DACB: 42317) has already been deposited in the Herbarium for further reference. The fresh leaves were dark dried for one week and grinded to a fine powder. Powdered dried leaves (300 g) were macerated with $1000 \mathrm{~mL}$ of methanol with occasional stirring at $25 \pm 2{ }^{\circ} \mathrm{C}$ for 3 days in a beaker. The extract was then filtered using a Whatman No. 1 filter paper and a sterilized cotton filter. The solvent was completely removed by rotary evaporator (BC-R 201 Shanghai Biochemical
Equipment Co. Ltd.) and 17.59 g extract (Yield 5.86\%) was obtained. This extract was used for the acute toxicity and antinociceptive activity studies.

\section{Animals}

Swiss albino mice (20-25 g) were collected from the Animal Research Branch of the International Center for Diarrheal Disease and Research, Bangladesh (ICDDR, B). Animals were kept under standard laboratory conditions (room temperature: $25.0 \pm 2.0{ }^{\circ} \mathrm{C}$, relative humidity: $55-$ $65 \%$ and $12 \mathrm{~h}$ light/dark cycle) with food and water during the adaptation period. The animals were acclimated to the laboratory environment for a period of two weeks prior to performing the experiments. Mice were fasted overnight prior to the experiments. All the experimental animals were treated following the Ethical Principles and Guidelines for Scientific Experiments on Animals (1995) formulated by The Swiss Academy of Medical Sciences and the Swiss Academy of Sciences. The Ethics Committee of Stamford University Bangladesh (SUB/IAEC/ 16.01) approved all experimental protocols.

\section{Drugs and treatments}

The control group orally received deionized water at the volume of $0.1 \mathrm{~mL} /$ mouse $30 \mathrm{~min}$ before the experiments. The positive control group intraperitoneally (i.p.) received standard drug morphine in hot plate, and tail immersion test at the dose of $5 \mathrm{mg} / \mathrm{kg}$ and diclofenac sodium in acetic acid-induced writhing, formalininduced licking, glutamate-induced paw licking, and cinnamaldehyde-induced licking test at the dose of $10 \mathrm{mg} / \mathrm{kg} 15 \mathrm{~min}$ before the experiments. MEDS was administered orally at the doses of 100,200 , and $400 \mathrm{mg} /$ $\mathrm{kg}$ (b.w.) $30 \mathrm{~min}$ before the experiments. To evaluate the involvement of opioid-mediated antinociceptive activity, naloxone was administered (i.p.) at the dose of $2 \mathrm{mg} / \mathrm{kg}$ $15 \mathrm{~min}$ before morphine sulfate $(5 \mathrm{mg} / \mathrm{kg}$, i.p.) or MEDS (100, 200, and $400 \mathrm{mg} / \mathrm{kg}$, p.o.) administration in the hot plate and tail immersion test. Methylene blue $(20 \mathrm{mg} /$ $\mathrm{kg}$ ) and glibenclamide $(10 \mathrm{mg} / \mathrm{kg})$ were intraperitoneally employed $15 \mathrm{~min}$ before control (Equivalent volume of deionized water, $0.1 \mathrm{~mL} / \mathrm{mouse}$, p.o.), or MEDS (100, 200, and $400 \mathrm{mg} / \mathrm{kg}$, p.o.) administration to evaluate the involvement of cyclic guanosine monophosphate (cGMP) and ATP-sensitive $\mathrm{K}^{+}$channel pathway respectively. All the doses of drugs and MEDS were prepared using deionized water.

\section{Acute toxicity test}

Acute toxicity studies were carried on mice according to the method proposed by Ghosh, MEDS at the doses of 50, $100,300,1000$, and $3000 \mathrm{mg} / \mathrm{kg}$ body weight were orally administered to separate groups of the mice $(n=5)$ after overnight fasting. Subsequent to administration of MEDS, 
the mice observed closely for the first $3 \mathrm{~h}$ for toxic manifestations like enlarged motor activity, salvation, convulsions, coma, and death. The observations were made at regular intervals for $24 \mathrm{~h}$. The animals were observed for one week [34].

\section{Phytochemical screening}

The crude methanolic extract of D. sissoo (MEDS) was qualitatively tested for the detection of alkaloids, flavonoids, saponins, tannins, glycosides, carbohydrates, reducing sugars, proteins, glucosides, terpenoids, and steroids following standard procedures [35].

\section{Antinociceptive activity test Hot plate test}

The hot plate test method was employed for the purpose of preferential assessment of possible centrally mediated analgesic effects [36]. Mice were divided into five groups of five mice each. Mice were treated with control (Equivalent volume of deionized water, $0.1 \mathrm{~mL} / \mathrm{mouse}$, p.o.), morphine as a standard drug (5 mg/kg, i.p.) or MEDS (100, 200 and $400 \mathrm{mg} / \mathrm{kg}$, p.o.) and was placed on Eddy's hot plate kept at a temperature of $52 \pm 1{ }^{\circ} \mathrm{C}$. A cut off period of the 20s was maintained to avoid paw tissue damage. The response in the form of forepaw licking, withdrawal symptom of the paws or jumping was recorded at $0,30,60,90$, and $120 \mathrm{~min}$ following treatment. Then, the percentage of the highest possible effect (\% MPE) was calculated using the following formula:

$$
\% \mathrm{MPE}=[(\text { Postdrug latency })-(\text { Predrug latency }) /
$$

$$
\text { (Cut off time) - (Pre-drug latency)] } \times 100 \text {. }
$$

\section{Tail immersion test}

The tail immersion test is based upon the observation that morphine-like drugs selectively prolongs the reaction time of the typical tail withdrawal reflex in mice. This method was used to evaluate the central mechanism of analgesic activity. Here, the painful reactions in animals were produced by the thermal incentive that is dipping by the tip of the tail in hot water [37]. Mice were divided into five groups consisting of five mice in each group. According to the procedure, 1 to $2 \mathrm{~cm}$ of the tail of mice pretreated with morphine $(5 \mathrm{mg} / \mathrm{kg}$, i.p.) or MEDS (100, 200 and $400 \mathrm{mg} / \mathrm{kg}$, p.o.) were immersed in warm water kept constant at $54 \pm 1{ }^{\circ} \mathrm{C}$. The latency between tail submersion and deflection of the tail was recorded. A latency period of the $20 \mathrm{~s}$ was maintained to avoid tail tissue damage in mice. The latency period of the tail-withdrawal response was taken as the indicator of antinociception and was determined at $0,30,60,90$, and $120 \mathrm{~min}$ after the administration of the morphine and MEDS. Then, the \% MPE was calculated from using the same formula used in hot plate test.

\section{Acetic acid-induced writhing test}

This test was performed to estimate the peripheral antinociceptive activity of MEDS in chemical-induced pain. The animals were divided into five groups $(n=5)$. The animals were treated with control (Equivalent volume of deionized water, $0.1 \mathrm{~mL} / \mathrm{mouse}$, p.o.), standard drug (Diclofenac sodium, $10 \mathrm{mg} / \mathrm{kg}$, i.p.) or MEDS (100, 200 and $400 \mathrm{mg} / \mathrm{kg}$, p.o.) and then the writhing was induced by the injection of $0.6 \%$ acetic acid $15 \mathrm{~min}$ after drug and $30 \mathrm{~min}$ after oral administration of MEDS, respectively. 5 min after the injection of acetic acid, the mice were observed and the number of writhing was counted for $30 \mathrm{~min}$ [38]. The contractions of the stomach, elongation of the body, twisting of the trunk and pelvis finishing with the extension of the limbs were considered as complete writhing. Antinociceptive activity was calculated as the percentage inhibition of abdominal constriction.

\section{Formalin test}

The method was used as narrating by Santos and Calixto and Santos et al. $[39,40]$ with minor modification. The animals were arranged into five groups $(n=5)$. The control group received deionized water orally at the volume of $0.1 \mathrm{~mL} /$ mouse $30 \mathrm{~min}$ before the experiments. Twenty microliters of $2.5 \%$ formalin (in deionized water, subplantar) was injected subcutaneously into the right hind paw $1 \mathrm{~h}$ after MEDS treatment (100, 200 and $400 \mathrm{mg} / \mathrm{kg}$, p.o.) and $15 \mathrm{~min}$ after injection of diclofenac sodium $(10 \mathrm{mg} /$ kg, i.p.) of the mice. The time spent licking and biting the injected paw was measured as an indicator of pain response. Responses were measured for 5 min subsequent to formalin injection (First phase, neurogenic) and 1530 min after formalin injection (Second phase, inflammatory). Antinociceptive activity was calculated as the percentage inhibition of licking time.

\section{Glutamate-induced nociception}

The method was used similarly to the previously described by Beirith et al. [41]. Mice were divided into five groups each containing five mice. A volume of $20 \mu \mathrm{L}$ of glutamate solution $(10 \mu \mathrm{mol}$ per paw $)$ was injected under the plantar surface of the right hind paw of the mice $30 \mathrm{~min}$ after MEDS (100, 200 and $400 \mathrm{mg} / \mathrm{kg}$, p.o.) treatment, respectively and $15 \mathrm{~min}$ after injection of diclofenac sodium $(10 \mathrm{mg} / \mathrm{kg}$, i.p.). The control group received deionized water orally at the volume of $0.1 \mathrm{~mL} /$ mouse $30 \mathrm{~min}$ before the experiments. The mice were observed separately for $15 \mathrm{~min}$ following glutamate injection. The number of licking of its injected paw was indicative of nociception. 


\section{Cinnamaldehyde-induced nociception}

In order to provide more direct evidence, concerning the participation of TRPA1 in the effect of the MEDS, investigated its antinociceptive effect in cinnamaldehydeinduced licking test in the mouse paw [42]. The experimental animals were randomly divided into five groups consisting of 5 mice in each. After an adjustment period (20 $\mathrm{min}), 20 \mu \mathrm{l}$ of cinnamaldehyde $(10 \mathrm{nmol} / \mathrm{paw})$ was injected into the ventral surface of the right hind paw of the mice $60 \mathrm{~min}$ after MEDS $(100,200$ and $400 \mathrm{mg} / \mathrm{kg}$, p.o.) treatment and $15 \mathrm{~min}$ after injection of diclofenac sodium $(10 \mathrm{mg} / \mathrm{kg}$, i.p.). The control group received deionized water orally at the volume of $0.1 \mathrm{~mL} / \mathrm{mouse}$ $30 \mathrm{~min}$ before the experiments. Mice were observed from 0 to $5 \mathrm{~min}$. (Neurogenic phase) and considered as indicative of nociception.

\section{Analysis of the possible mechanism of action of MEDS Involvement of opioid system}

The possible connection of the opioid system in the antinociceptive effect of MEDS was examined by injecting naloxone hydrochloride (2 $\mathrm{mg} / \mathrm{kg}$, i.p.), a nonselective opioid receptor antagonist, and $15 \mathrm{~min}$ prior to the administration of either morphine or MEDS (100, 200 and $400 \mathrm{mg} / \mathrm{kg}$, p.o.). Then, the hot plate and tail immersion latencies were measured at $0,30,60,90$, and 120 min with the same cut off time of the 20 s for the protection of animals [43].

\section{Involvement of cyclic guanosine monophosphate (cGMP) pathway}

To investigate the possible involvement of cGMP pathway to the antinociceptive effect of MEDS, mice were pre-treated with methylene blue $(20 \mathrm{mg} / \mathrm{kg})$, a nonspecific inhibitor of nitric oxide/guanylyl cyclase, intraperitonially $15 \mathrm{~min}$ before the administration of diclofenac sodium or MEDS (100, 200 and $400 \mathrm{mg} / \mathrm{kg}$, p.o.). Then, the nociceptive responses against $0.6 \%$ acetic acid injection were seen for $30 \mathrm{~min}$, opening from $5 \mathrm{~min}$ post injection. The numbers of abdominal writhing were counted as the symptom of pain behavior [44, 45].

\section{Involvement of ATP-sensitive $K^{+}$channels pathway}

The possible contribution of $\mathrm{K}^{+}$channels in the antinociceptive effect of MEDS was evaluated by using the method described by Mohamad et al. with slide modification [46]. The mice were pre-treated with glibenclamide $(10 \mathrm{mg} / \mathrm{kg})$, an ATP-sensitive $\mathrm{K}^{+}$channel inhibitor, intraperitoneally 15 min before the administration of either diclofenac sodium or MEDS (100, 200 and $400 \mathrm{mg} /$ $\mathrm{kg}$, p.o.). The mice were challenged with i.p. injection of $0.6 \%$ acetic acid, 30 min post-treatment. Subsequent the injection of acetic acid, the mice were immediately placed in a circle box and the number of writhing was recorded for $30 \mathrm{~min}$, starting from $5 \mathrm{~min}$ post injection.

\section{Statistical analysis}

The results are presented as mean \pm SEM. The statistical analysis was performed using one-way analysis of variance (ANOVA) followed by Dunnett's post hoc test as appropriate using SPSS 18.00 software. Differences between groups were considered significant at a level of $p<0.001$.

\section{Results}

\section{Phytochemical screening}

The phytochemical screening of the crude extract of $D$. sissoo revealed the presence of flavonoids, tannins, cardiac glycosides, carbohydrates, proteins, and terpenoids (Table 1).

\section{Acute toxicity test}

In the acute toxicity study, all mice survived and did not manifest any sign of toxicity and abnormality at the doses of 50-3000 mg/kg. After oral administration, there was no behavioral or body weight changes and no abnormal signs were observed for a period of 7 days. Therefore, it can be indicated that MEDS has low toxicity profile and the $\mathrm{LD}^{50}$ is more than $3000 \mathrm{mg} / \mathrm{kg}$.

\section{Hot plate test}

As presented in Fig. 1 and Table 2, MEDS showed a significant antinociceptive effect at the doses of $200 \mathrm{mg} / \mathrm{kg}$ and $400 \mathrm{mg} / \mathrm{kg}(p<0.05)$. The administration of naloxone did not cause any significant attenuation of antinociceptive activity of MEDS. Moreover, administration of morphine at the dose of $5 \mathrm{mg} / \mathrm{kg}$ confirmed a significant antinociceptive effect $(p<0.01)$ when compared with control group (Deionized water).

Table 1 Preliminary qualitative phytochemical screening of methanolic extract of D. sissoo (MEDS)

\begin{tabular}{ll}
\hline Plant constituents & Inference \\
\hline Alkaloids & - \\
Flavonoids & +++ \\
Saponins & - \\
Tannins & ++ \\
Cardiac Glycosides & + \\
Carbohydrates & + \\
Reducing Sugars & - \\
Proteins & + \\
Glucosides & - \\
Terpenoids & + \\
Steroids & - \\
\hline
\end{tabular}

+++: Most prominent; ++: Moderate; +: Lower; -: Absence 


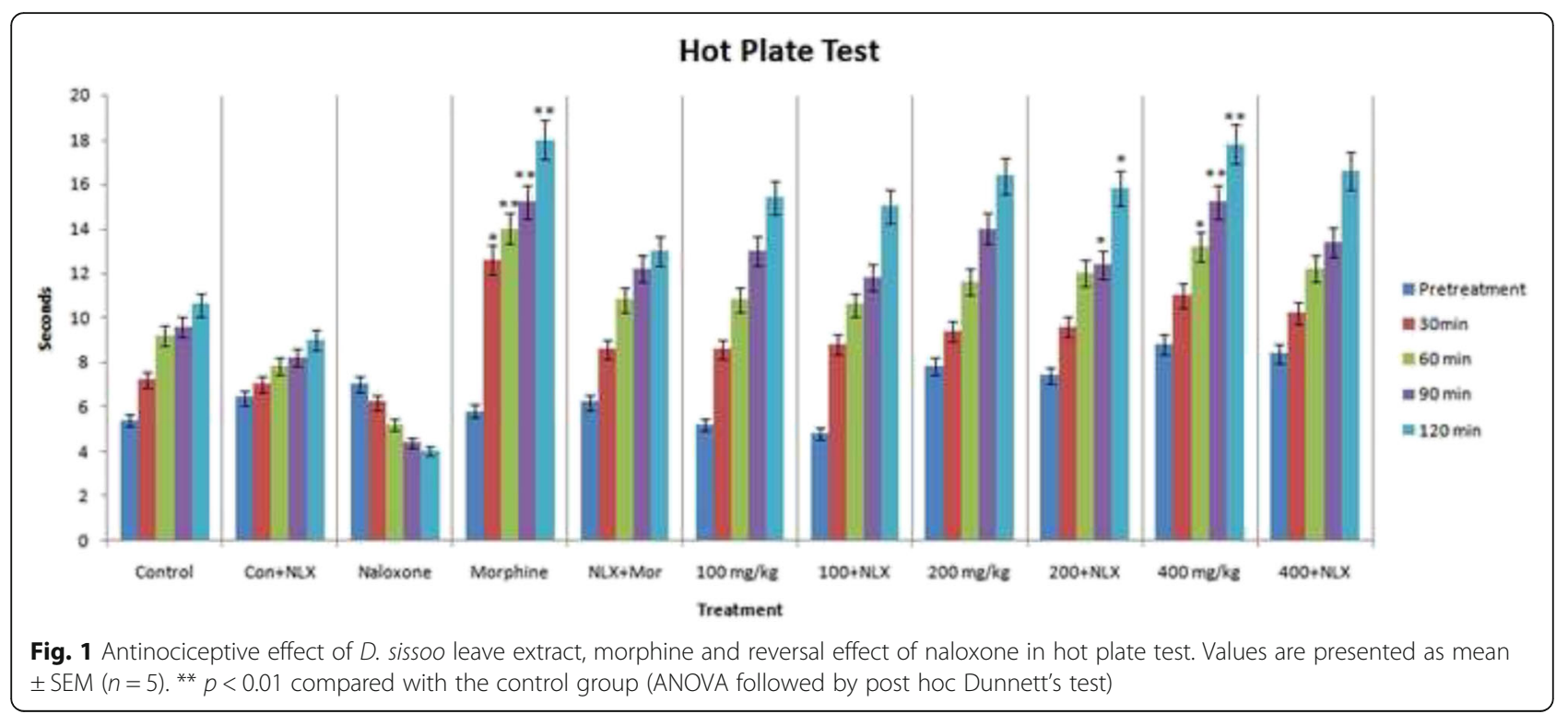

\section{Tail immersion test}

The tail-immersion test results asserted significant antinociceptive effect $(p<0.001)$ compared with control, at the doses of 200 and $400 \mathrm{mg} / \mathrm{kg}$. The antinociceptive effect of 100, 200, and $400 \mathrm{mg} / \mathrm{kg}$ of MEDS were comparable to that of the reference drug (Fig. 2 and Table 3). The antinociceptive activity of morphine used in this test was antagonized by naloxone. The effect of naloxone was not remarkable at any of the doses. A significant antinociceptive effect was produced by morphine $(p<$ 0.001 ) when compared with control group (Deionized water).

\section{Acetic acid-induced writhing test}

The effect of administration of MEDS using the abdominal constriction test in mice is shown in Fig. 3 and

Table 2 Antinociceptive effect of D. sissoo leave extract, morphine and reversal effect of naloxone in hot plate test

\begin{tabular}{|c|c|c|c|c|c|c|c|}
\hline Treatment & & Dose (mg/kg) & $\begin{array}{l}\text { Latency period (s) (\% MPE) } \\
\text { Pretreatment }\end{array}$ & $30 \mathrm{~min}$ & $60 \mathrm{~min}$ & $90 \mathrm{~min}$ & $120 \mathrm{~min}$ \\
\hline \multirow{5}{*}{$\begin{array}{l}\text { Treatment without } \\
\text { Naloxone }\end{array}$} & Control & $0.1 \mathrm{~mL} / \mathrm{mouse}$ & $5.40 \pm 1.20$ & $7.20 \pm 1.56$ & $9.20 \pm 0.86$ & $9.60 \pm 1.07$ & $10.60 \pm 1.07$ \\
\hline & Morphine & 5 & $5.82 \pm 0.86$ & $\begin{array}{l}12.60 \pm 0.92^{*} \\
(42.19)\end{array}$ & $\begin{array}{l}14.00 \pm 0.70^{* *} \\
(44.44)\end{array}$ & $\begin{array}{l}15.20 \pm 0.86^{* *} \\
(53.84)\end{array}$ & $\begin{array}{l}18.00 \pm 1.14^{* *} \\
(78.72)\end{array}$ \\
\hline & MEDS & 100 & $5.20 \pm 0.97$ & $\begin{array}{l}8.60 \pm 2.01 \\
(10.93)\end{array}$ & $\begin{array}{l}10.80 \pm 0.86 \\
(14.81)\end{array}$ & $\begin{array}{l}13.00 \pm 1.00 \\
(32.69)\end{array}$ & $\begin{array}{l}15.40 \pm 1.28 \\
(51.06)\end{array}$ \\
\hline & MEDS & 200 & $7.80 \pm 1.46$ & $\begin{array}{l}9.40 \pm 0.92 \\
(17.18)\end{array}$ & $\begin{array}{l}11.60 \pm 1.20 \\
(22.22)\end{array}$ & $\begin{array}{l}14.00 \pm 1.22^{*} \\
(42.30)\end{array}$ & $\begin{array}{l}16.40 \pm 1.53^{*} \\
(61.70)\end{array}$ \\
\hline & MEDS & 400 & $8.80 \pm 1.24$ & $\begin{array}{l}11.00 \pm 0.70 \\
(29.68)\end{array}$ & $\begin{array}{l}13.20 \pm 1.06^{*} \\
(37.03)\end{array}$ & $\begin{array}{l}15.20 \pm 1.15^{* *} \\
(53.84)\end{array}$ & $\begin{array}{l}17.80 \pm 1.53^{* *} \\
(76.59)\end{array}$ \\
\hline \multirow{6}{*}{$\begin{array}{l}\text { Treatment with } \\
\text { Naloxone }\end{array}$} & $N L X$ & 2 & $7.00 \pm 0.70$ & $6.20 \pm 0.58$ & $5.20 \pm 0.66$ & $4.40 \pm 0.51$ & $4.00 \pm 0.70$ \\
\hline & NLX+ Control & $2+0.1 \mathrm{~mL} /$ mouse & $6.64 \pm 0.74$ & $7.00 \pm 0.70$ & $7.80 \pm 0.86$ & $8.20 \pm 0.86$ & $9.00 \pm 0.89$ \\
\hline & NLX+ Morphine & $2+5$ & $6.20 \pm 0.58$ & $\begin{array}{l}8.60 \pm 0.51 \\
(10.93)\end{array}$ & $\begin{array}{l}10.80 \pm 0.73 \\
(14.81)\end{array}$ & $\begin{array}{l}12.20 \pm 0.86 \\
(25)\end{array}$ & $\begin{array}{l}13.00 \pm 1.14 \\
(25.53)\end{array}$ \\
\hline & NLX+ MEDS & $2+100$ & $4.80 \pm 0.58$ & $\begin{array}{l}8.80 \pm 0.66 \\
(12.50)\end{array}$ & $\begin{array}{l}10.60 \pm 0.51 \\
(12.96)\end{array}$ & $\begin{array}{l}11.80 \pm 0.80 \\
(21.15)\end{array}$ & $\begin{array}{l}15.00 \pm 0.70 \\
(46.80)\end{array}$ \\
\hline & NLX+ MEDS & $2+200$ & $7.40 \pm 1.20$ & $\begin{array}{l}9.60 \pm 0.67 \\
(18.75)\end{array}$ & $\begin{array}{l}12.00 \pm 0.70 \\
(25.92)\end{array}$ & $\begin{array}{l}12.40 \pm 0.92 \\
(26.92)\end{array}$ & $\begin{array}{l}15.80 \pm 1.59 \\
(55.31)\end{array}$ \\
\hline & NLX+ MEDS & $2+400$ & $8.40 \pm 0.81$ & $\begin{array}{l}10.20 \pm 0.58 \\
(23.43)\end{array}$ & $\begin{array}{l}12.20 \pm 0.37 \\
(27.77)\end{array}$ & $\begin{array}{l}13.40 \pm 0.92 \\
(36.52)\end{array}$ & $\begin{array}{l}16.60 \pm 1.43 \\
(63.82)\end{array}$ \\
\hline
\end{tabular}




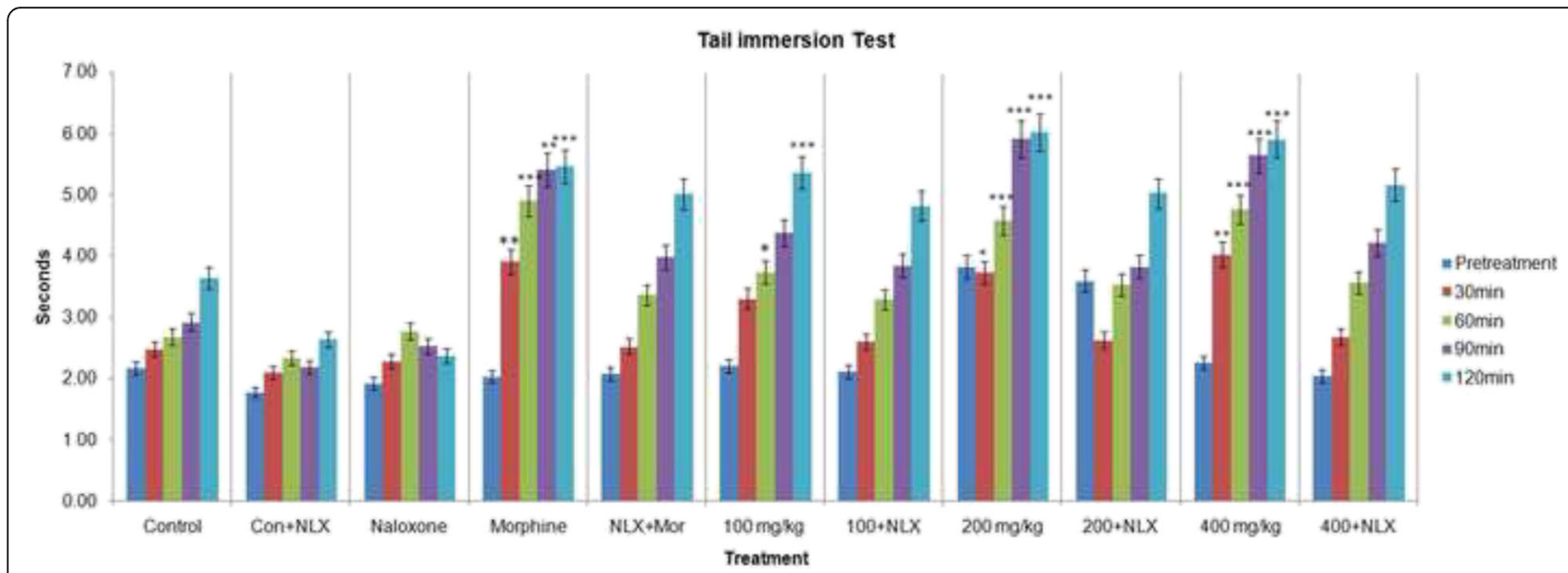

Fig. 2 Antinociceptive effect of $D$. sissoo leave extract, morphine and reversal effect of naloxone in tail immersion test. Values are presented as mean $\pm \operatorname{SEM}(n=5) .{ }^{* * *} p<0.001$ compared with the control group (ANOVA followed by post hoc Dunnett's test)

Table 4. It was found that MEDS was able to inhibit significantly the nociceptive effects induced by acetic acid compared to the control group (Deionized water) at the doses of 100,200 , and $400 \mathrm{mg} / \mathrm{kg}$, respectively $(p<$ $0.001)$. The percentage inhibition of constrictions was calculated as $70.36 \%$ (Diclofenac sodium, $10 \mathrm{mg} / \mathrm{kg}$ ), 35.18\% (MEDS, $100 \mathrm{mg} / \mathrm{kg}$ ), 48.53\% (MEDS, $200 \mathrm{mg} /$ $\mathrm{kg}$ ), and $67.10 \%$ (MEDS, $400 \mathrm{mg} / \mathrm{kg}$ ) (Table 4).

\section{Formalin test}

MEDS produced a dose-related inhibition of formalininduced nociception and caused significant inhibition of both neurogenic (0-5 min) and inflammatory (15$30 \mathrm{~min}$ ) phases of formalin-induced licking test at the doses of 100, 200, and $400 \mathrm{mg} / \mathrm{kg}$ when compared with control group (Deionized water) (Fig. 4 and Table 5). However, its antinociceptive effect was more pronounced

Table 3 Antinociceptive effect of D. sissoo leave extract, morphine and reversal effect of naloxone in tail immersion test

\begin{tabular}{|c|c|c|c|c|c|c|c|}
\hline Treatment & & Dose (mg/kg) & $\begin{array}{l}\text { Latency period (s) (\% MPE) } \\
\text { Pretreatment }\end{array}$ & $30 \mathrm{~min}$ & $60 \mathrm{~min}$ & $90 \mathrm{~min}$ & $120 \mathrm{~min}$ \\
\hline \multirow{5}{*}{$\begin{array}{l}\text { Treatment without } \\
\text { Naloxone }\end{array}$} & Control & $0.1 \mathrm{~mL} / \mathrm{mouse}$ & $2.16 \pm 0.23$ & $2.48 \pm 0.16$ & $2.68 \pm 0.19$ & $2.92 \pm 0.12$ & $3.64 \pm 0.14$ \\
\hline & Morphine & 5 & $2.03 \pm 0.15$ & $\begin{array}{l}3.90 \pm 0.18^{* *} \\
(8.10)\end{array}$ & $\begin{array}{l}4.90 \pm 0.18^{* * *} \\
(12.81)\end{array}$ & $\begin{array}{l}5.40 \pm 0.40^{* *} \\
(14.51)\end{array}$ & $\begin{array}{l}5.46 \pm 0.25^{* * *} \\
(11.12)\end{array}$ \\
\hline & MEDS & 100 & $2.20 \pm 0.20$ & $\begin{array}{l}3.30 \pm 0.12 \\
(4.68)\end{array}$ & $\begin{array}{l}3.73 \pm 0.15^{*} \\
(6.08)\end{array}$ & $\begin{array}{l}4.37 \pm 0.21 \\
(8.50)\end{array}$ & $\begin{array}{l}5.36 \pm 0.24^{* * *} \\
(10.51)\end{array}$ \\
\hline & MEDS & 200 & $3.81 \pm 0.18$ & $\begin{array}{l}3.72 \pm 0.27^{*} \\
(7.10)\end{array}$ & $\begin{array}{l}4.58 \pm 0.45^{* * *} \\
(10.94)\end{array}$ & $\begin{array}{l}5.91 \pm 0.68^{* * *} \\
(17.49)\end{array}$ & $\begin{array}{l}6.02 \pm 0.14^{* * *} \\
(14.53)\end{array}$ \\
\hline & MEDS & 400 & $2.26 \pm 0.09$ & $\begin{array}{l}4.02 \pm 0.43^{* *} \\
(8.80)\end{array}$ & $\begin{array}{l}4.76 \pm 0.23^{* * *} \\
(12.00)\end{array}$ & $\begin{array}{l}5.64 \pm 0.37^{* * *} \\
(15.92)\end{array}$ & $\begin{array}{l}5.90 \pm \\
0.18^{* * *}(13.81)\end{array}$ \\
\hline \multirow{6}{*}{$\begin{array}{l}\text { Treatment with } \\
\text { Naloxone }\end{array}$} & NLX & 2 & $1.92 \pm 0.13$ & $2.28 \pm 0.16$ & $2.77 \pm 0.15$ & $2.53 \pm 0.16$ & $2.37 \pm 0.18$ \\
\hline & NLX+ Control & $\begin{array}{l}2+0.1 \mathrm{~mL} / \\
\text { mouse }\end{array}$ & $1.77 \pm 0.10$ & $2.09 \pm 0.16$ & $2.33 \pm 0.14$ & $2.18 \pm 0.11$ & $2.63 \pm 0.11$ \\
\hline & $\begin{array}{l}\text { NLX+ } \\
\text { Morphine }\end{array}$ & $2+5$ & $2.08 \pm 0.05$ & $\begin{array}{l}2.52 \pm 0.13 \\
(0.22)\end{array}$ & $\begin{array}{l}3.36 \pm 0.18 \\
(3.92)\end{array}$ & $\begin{array}{l}3.98 \pm 0.37 \\
(6.20)\end{array}$ & $\begin{array}{l}5.01 \pm 0.30 \\
(8.36)\end{array}$ \\
\hline & NLX+ MEDS & $2+100$ & $2.11 \pm 0.14$ & $\begin{array}{l}2.60 \pm 0.11 \\
(0.68)\end{array}$ & $\begin{array}{l}3.29 \pm 0.15 \\
(3.52)\end{array}$ & $\begin{array}{l}3.84 \pm 0.39 \\
(5.38)\end{array}$ & $\begin{array}{l}4.82 \pm 0.09 \\
(7.21)\end{array}$ \\
\hline & NLX+ MEDS & $2+200$ & $3.59 \pm 1.14$ & $\begin{array}{l}2.63 \pm 0.18 \\
(0.85)\end{array}$ & $\begin{array}{l}3.52 \pm 0.29 \\
(4.84)\end{array}$ & $\begin{array}{l}3.82 \pm 0.37 \\
(5.24)\end{array}$ & $\begin{array}{l}5.02 \pm 0.13 \\
(8.43)\end{array}$ \\
\hline & NLX+ MEDS & $2+400$ & $2.04 \pm 0.07$ & $\begin{array}{l}2.68 \pm 0.27 \\
(1.14)\end{array}$ & $\begin{array}{l}3.56 \pm 0.34 \\
(5.09)\end{array}$ & $\begin{array}{l}4.21 \pm 0.25 \\
(7.56)\end{array}$ & $\begin{array}{l}5.16 \pm 0.16 \\
(9.29)\end{array}$ \\
\hline
\end{tabular}

Values are presented as mean \pm SEM $(n=5)$. MEDS Methanolic extract of $D$. sissoo, NLX Naloxone

*** $p<0.001$ compared with the control group (Dunnett's test)

** $p<0.01$ compared with the control group (Dunnett's test)

${ }^{*} p<0.05$ compared with the control group (Dunnett's test) 


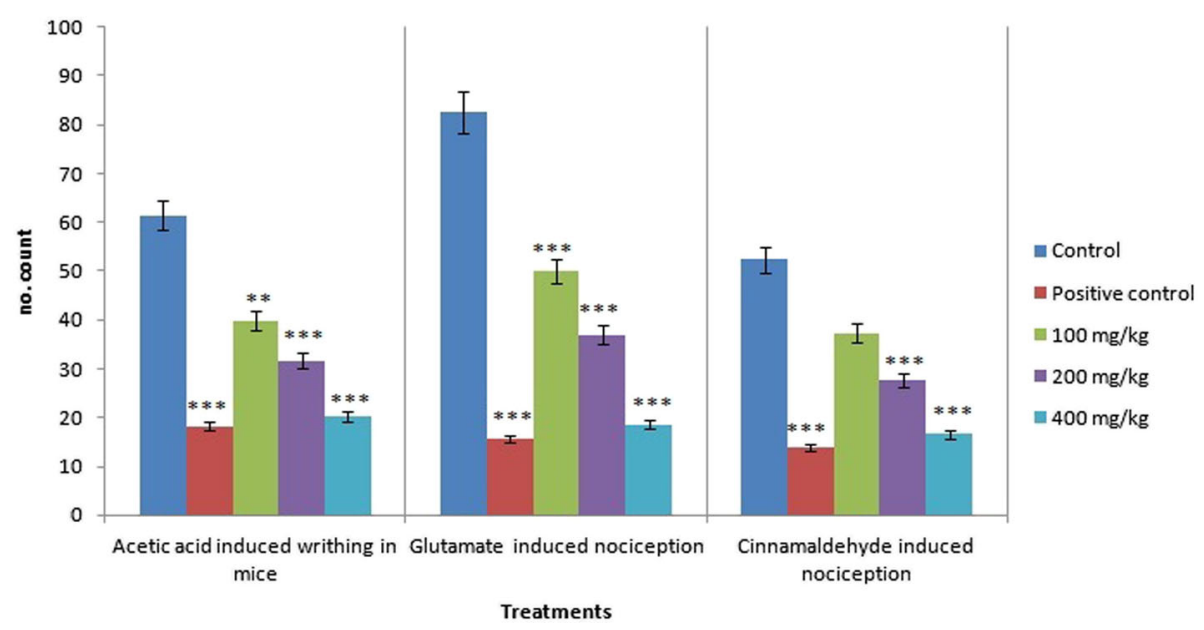

Fig. 3 Antinociceptive effects of D. sissoo leave extract in acetic acid-induced writhing, glutamate-induced nociception and cinnamaldehyde-induced nociception tests. All values are presented as mean $\pm \operatorname{SEM}(n=5) .{ }^{* *} p<0.001$ compared with the control group (ANOVA followed by post hoc Dunnett's test)

in the second phase of this model of pain. Diclofenac sodium $(10 \mathrm{mg} / \mathrm{kg}$, i.p.) significantly reduced formalininduced nociception in both phases $(p<0.001)$.

\section{Glutamate-induced nociception}

The antinociceptive activity induced by oral administration of MEDS was dose-dependent. It showed that MEDS at the doses of 100,200 , and $400 \mathrm{mg} / \mathrm{kg}$ produced significant prohibition of the glutamate-induced nociception test (Fig. 3 and Table 6). Diclofenac sodium $(10 \mathrm{mg} / \mathrm{kg})$ was used as a standard drug, which showed $81.11 \%$ inhibition of licking as compared to the control group. All treatments displayed significant antinociceptive activity $(p<0.001)$ compared together with the control group (Deionized water).

\section{Cinnamaldehyde-induced nociception}

The result of cinnamaldehyde-induced nociception showed that administration of MEDS at 100, 200, and $400 \mathrm{mg} / \mathrm{kg}$ dose produced dose-dependent inhibition of the cinnamaldehyde-induced neurogenic nociception

Table 4 Antinociceptive effects of $D$. sissoo leave extract in acetic acid-induced writhing test

\begin{tabular}{llll}
\hline Treatment & Dose $(\mathrm{mg} / \mathrm{kg})$ & Number of writhing & Inhibition (\%) \\
\hline Control & $0.1 \mathrm{~mL} /$ mouse & $61.4 \pm 1.29$ & \\
Diclofenac sodium & 10 & $18.2 \pm 2.25^{* * *}$ & 70.36 \\
MEDS & 100 & $39.8 \pm 1.78^{* *}$ & 35.18 \\
MEDS & 200 & $31.6 \pm 1.69^{* * *}$ & 48.53 \\
MEDS & 400 & $20.2 \pm 1.60^{* * *}$ & 67.10
\end{tabular}

Values are presented as mean \pm SEM $(n=5)$. MEDS Methanolic extract of D. sissoo

*** $p<0.001$ compared with the control group (Dunnett's test)

** $p<0.01$ compared with the control group (Dunnett's test) with the percentage of inhibition of $28.62 \%, 47.32 \%$ and 68.32\%, respectively (Fig. 3 and Table 7). Only $100 \mathrm{mg} /$ kg MEDS treatment showed no significant difference compared with the control group (Deionized water), at the same time as the rest showed significant antinociceptive activity $(p<0.001)$.

\section{Involvement of cyclic guanosine monophosphate (cGMP) pathway}

The present results showed at the effects of 100, 200, and $400 \mathrm{mg} / \mathrm{kg}$ MEDS and methylene blue $(20 \mathrm{mg} / \mathrm{kg})$ treatments. Methylene blue administration alone significantly inhibited acetic acid-induced abdominal writhing (Fig. 5 and Table 8). Given together, methylene blue significantly $(p<0.001)$ increased MEDS $(200$, and $400 \mathrm{mg} /$ $\mathrm{kg}$ ) induced antinociception compared to the control group (Deionized water).

\section{Involvement of ATP-sensitive $\mathrm{K}^{+}$channels pathway}

The present study seemed at the effects of 100, 200, and $400 \mathrm{mg} / \mathrm{kg}$ MEDS and glibenclamide $(10 \mathrm{mg} / \mathrm{kg})$ treatments. It was found out that glibenclamide $(10 \mathrm{mg} / \mathrm{kg})$ administration alone did not alter abdominal writhing count when assessed through the injection of $0.6 \%$ acetic acid (Fig. 5 and Table 9). When given together, the antinociceptive activity of MEDS was noticeably decreased by glibenclamide at the doses of 200 , and $400 \mathrm{mg} / \mathrm{kg}$, respectively.

\section{Discussion}

The study investigated the antinociceptive activity of MEDS in classical pharmacological models of pain. The findings of this study specify the peripheral and central antinociceptive effect of MEDS at different doses in mice 


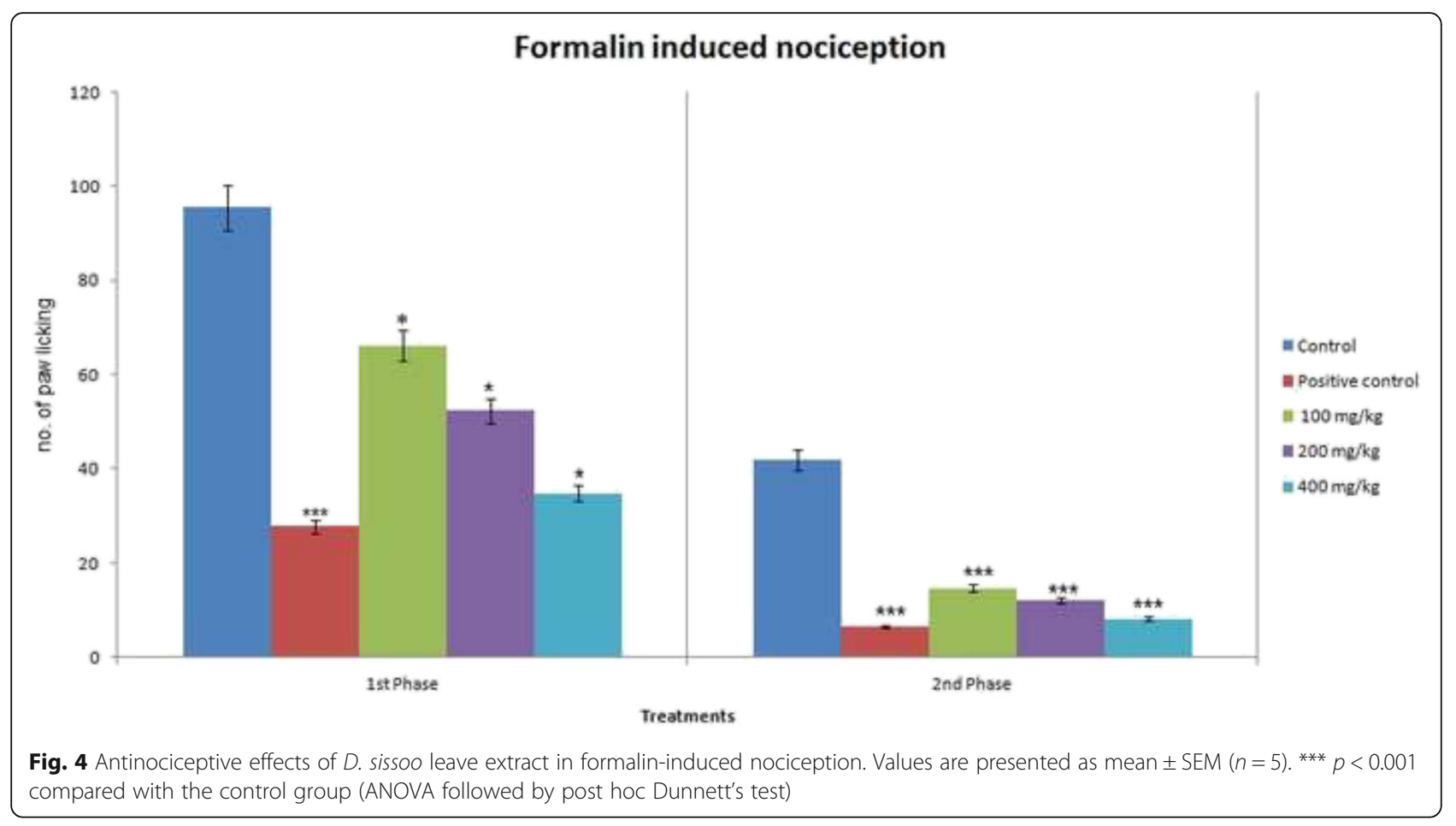

models. The hot plate latency time was dosedependently enhanced by MEDS $(p<0.05)$ at different doses suggest that the central antinociceptive activity of MEDS (Fig. 1 and Table 2). The effect is further supported by the results viewed in the tail immersion test (Fig. 2 and Table 3), as the tail removal response in hot water-induced pain is selective just for centrally acting analgesics, while the peripherally acting agents are inactive [47]. The results obtained from these two models suggest that antinociceptive effect of MEDS was reversed by naloxone, a non-selective opioid receptor antagonist, against the antinociceptive effect of MEDS. The central antinociceptive effect of MEDS may arise through opioid receptors of spinal as well as a supraspinal system. Both tail immersion and hot plate tests are based on measuring the response of the animal to thermal stimuli where the tail immersion check a spinal reflex, and the hot plate is used for supraspinal reflex [48]. Reach an agreement with this suggestion that $\mu 2$ - and $\delta$-opioid receptors are involved in spinal mechanism, while $\mu 1 / \mu 2$ opioid receptors may mediate principally supraspinal analgesia [49]. This clearly suggests that the involvement of the activation of opioid receptors in the antinociceptive action of MEDS.

In the acetic acid-induced writhing test, a dosedependent antinociceptive effect was observed after oral administration of MEDS (Fig. 3 and Table 4). This test has been used as a screening tool for assessing of the central and peripheral antinociceptive activity [50]. In general, acetic acid causes pain by liberating endogenous substances such as serotonin histamine, prostaglandins (PGs), bradykinins and substance P. Local peritoneal receptors are postulated to be occupied in the abdominal constrictions response [51]. Intraperitoneal administration of

Table 5 Antinociceptive effects of D. sissoo leave extract in formalin-induced nociception

\begin{tabular}{|c|c|c|c|c|c|}
\hline \multirow[t]{2}{*}{ Treatment } & \multirow[t]{2}{*}{ Dose $(\mathrm{mg} / \mathrm{kg})$} & \multicolumn{4}{|l|}{ Licking of the hind paw } \\
\hline & & Early phase (0-5 min) & Inhibition (\%) & Late phase (15-30 min) & Inhibition (\%) \\
\hline Control & $0.1 \mathrm{~mL} /$ mouse & $95.40 \pm 1.33$ & - & $41.80 \pm 2.15$ & - \\
\hline Diclofenac sodium & 10 & $27.80 \pm 2.73^{* * *}$ & 70.86 & $6.60 \pm 0.51^{* * *}$ & 84.21 \\
\hline MEDS & 100 & $66.20 \pm 1.98^{*}$ & 30.60 & $14.60 \pm 1.75^{* * *}$ & 65.05 \\
\hline MEDS & 200 & $52.40 \pm 0.87^{*}$ & 45.07 & $12.00 \pm 1.00^{* * *}$ & 71.29 \\
\hline MEDS & 400 & $34.80 \pm 1.20^{*}$ & 63.52 & $08.20 \pm 0.73^{* * *}$ & 80.38 \\
\hline
\end{tabular}

Values are presented as mean \pm SEM $(n=5)$. MEDS Methanolic extract of $D$. sissoo

*** $p<0.001$ compared with the control group (Dunnett's test)

${ }^{*} p<0.05$ compared with the control group (Dunnett's test) 
Table 6 Antinociceptive effects of D. sissoo leave extract in glutamate-induced nociception

\begin{tabular}{llll}
\hline Treatment & Dose $(\mathrm{mg} / \mathrm{kg})$ & Licking time $(\mathrm{s})$ & Inhibition (\%) \\
\hline Control & $0.1 \mathrm{~mL} / \mathrm{mouse}$ & $82.60 \pm 1.72$ & - \\
Diclofenac sodium & 10 & $15.60 \pm 1.08^{* * *}$ & 81.11 \\
MEDS & 100 & $50.00 \pm 1.61^{* * *}$ & 39.46 \\
MEDS & 200 & $37.00 \pm 1.30^{* * *}$ & 55.20 \\
MEDS & 400 & $18.60 \pm 1.36^{* * *}$ & 77.48 \\
\hline
\end{tabular}

Values are presented as mean \pm SEM $(n=5)$. MEDS Methanolic extract of D. sissoo

*** $p<0.001$ compared with the control group (Dunnett's test)

acetic acid causes an increment in cyclooxygenase (COX), lipoxygenase (LOX), prostaglandins (PGs), histamine, serotonin, bradykinin, substance P, IL- $1 \beta$, IL-8,TNF- $\alpha$ in the peripheral tissue fluid. These mediators cause the stimulation of primary afferent nociceptors entering dorsal horn of the central nervous system [52]. The release of these inflammatory mediators is thought to contribute to increased blood-brain barrier (BBB) permeabilization or interruption [53]. Moreover, injection of pain inducing agent like acetic acid is also responded to enhance vasodilation and vascular fluid permeability and these events were reversed by plant extracts [54]. From a mechanistic point of view, the lack of specificity in acetic acid-induced writhing test suggesting the participation of different nociceptive mechanisms in the reduction of muscular constriction such as sympathetic system throughout the release of biogenic amines, cyclooxygenases and their metabolites inhibition and through opioid receptors mechanisms [55]. Therefore, the inhibition of writhing response in the present study clearly indicated the peripheral antinociceptive effect of MEDS in addition to its central effect.

Formalin-induced test is a pain-related licking response of the injected paw in two distinct phases. The first phase is presented by neurogenic pain caused by direct chemical stimulation of nociceptors. The second phase is marked by inflammatory pain triggered by a fusion of stimuli-inflammation of the peripheral tissues and mechanisms of central sensitization. In this latter part, different mediators are involved, as excitatory

Table 7 Antinociceptive effects of $D$. sissoo leave extract in cinnamaldehyde-induced nociception

\begin{tabular}{llll}
\hline Treatment & Dose $(\mathrm{mg} / \mathrm{kg})$ & Licking time $(\mathrm{s})$ & Inhibition (\%) \\
\hline Control & $0.1 \mathrm{~mL} /$ mouse & $52.40 \pm 1.54$ & \\
Diclofenac sodium & 10 & $13.80 \pm 1.53^{* * *}$ & 73.66 \\
MEDS & 100 & $37.40 \pm 0.93$ & 28.62 \\
MEDS & 200 & $27.60 \pm 1.66^{* * *}$ & 47.32 \\
MEDS & 400 & $16.60 \pm 1.86^{* * *}$ & 68.32 \\
\hline
\end{tabular}

Values are presented as mean \pm SEM $(n=5)$. MEDS Methanolic extract of D. sissoo

*** $p<0.001$ compared with the control group (Dunnett's test) amino acids, neuropeptides, nitric oxide, $\mathrm{PGE}_{2}$, and kinins [56]. Our present results showed that the number of paw licking was significantly reduced by MEDS in both neurogenic and inflammatory pain responses $(p<$ 0.001) in a dose dependant manner (Fig. 4 and Table 5). However, the effect was more assert in the late phase. Centrally acting analgesic drugs inhibit both the phases of formalin test, while peripherally acting analgesics restrict only the late phase responses. Diclofenac sodium significantly suppressed the late phase pain response. The first phase finding of formalin test further confirms the central antinociceptive effect of MEDS that we have observed in the hot plate and tail immersion tests. The late phase response as the antinociceptive effect observed in acetic acid-induced writhing test is due to this inhibition of the inflammatory mediators [57].

Phytochemical screening exposed that flavonoids, tannins, cardiac glycosides, carbohydrates, proteins, and terpenoids are present in D. sissoo. The MEDS showed significant and dose-dependent antinociceptive activity due to the presence of flavonoids [23]. Flavonoids have been found to suppress the intracellular $\mathrm{Ca}^{2+}$ ion elevation in a dose-dependent manner, as well as possible the release of proinflammatory mediators such as TNF- $\alpha$ [58]. Flavonoids may enhance the amount of endogenous serotonin or may act together with $5-\mathrm{HT}_{2}$ and $5-\mathrm{HT}_{3}$ receptors, which may be involved in the mechanism of central pain reliever activity [59]. There are also reports on the role of flavonoid in analgesic activity principally by targeting prostaglandins [60]. Moreover, MEDS showed significant analgesic activity in the whole experimental model, which may be due to its high flavonoid. Furthermore, flavonoids have the capability to inhibit ecosanoid biosynthesis. Ecosanoids, such as prostaglandins are involved in different immunological responses and are the products of the cyclooxygenase and lipoxygenase pathways [61]. Tannins are also invented to have a contribution in antinociceptive activity [62]. Therefore, it can be agreed that cyclooxygenase (COX) inhibitory activity alongside with antioxidant activity may reduce the production of arachidonic acid from phospholipids or may reduce the enzyme system responsible for the synthesis of prostaglandins and finally relieve pain-sensation.

In another experiment to determine the role of the glutamatergic system in the modulation of MEDS antinociception, the extract was treated with the glutamateinduced paw-licking test. Previous reports have shown that the glutamate and glutamatergic receptors are very important in the peripheral, spinal, and supraspinal nociceptive neurotransmission [63-65], which is greatly mediated by both N-methyl-D-aspartate (NMDA) and non-NMDA receptors, as well as possible by the release of nitric oxide and nitric oxide-related substances [41]. 


\section{Mechanism of action study}

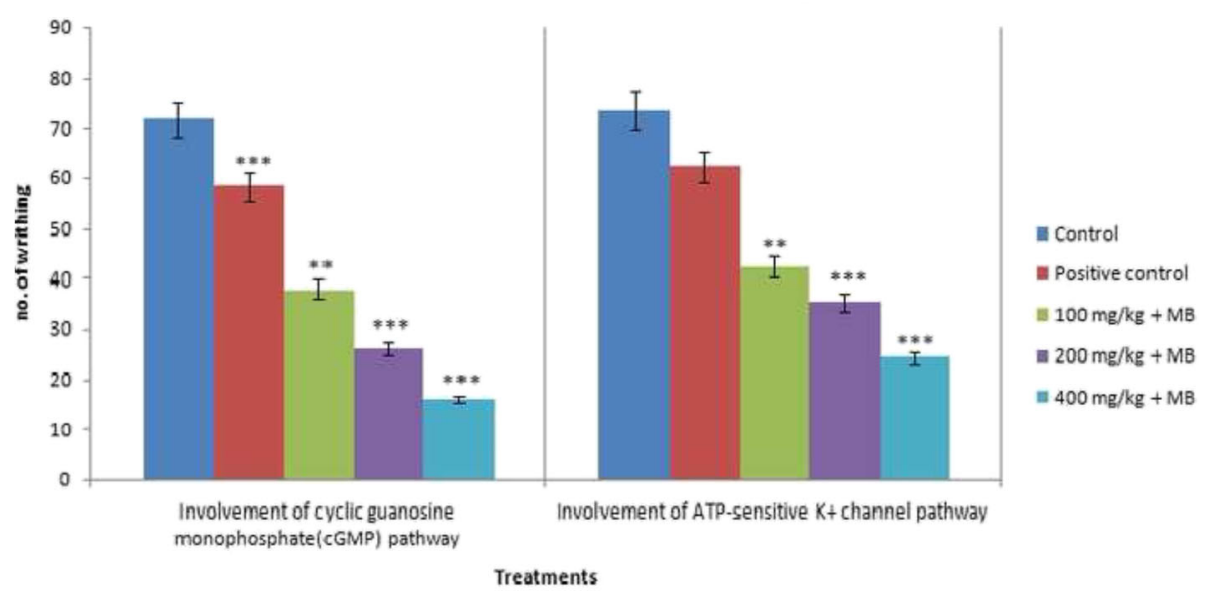

Fig. 5 Effects of D. sissoo leave extract on involvement of cyclic guanosine monophosphate (CGMP) pathway and ATP-sensitive $\mathrm{K}^{+}$channel pathway. Values are presented as mean $\pm \operatorname{SEM}(n=5) .{ }^{* *} p<0.001$ compared with the control group (ANOVA followed by post hoc Dunnett's test)

On the other hand, N-methyl-D-aspartate receptor antagonists have been proven to inhibit the spread of pain sensation and to decrease the hyperactive excitability of spinal cord neurons triggered by C-fiber stimulation $[66,67]$. In addition, activation of glutamate receptors also has been shown to contribute to the continuation of peripheral nociceptive processes that are connected with inflammatory pain [68], which is concurrent with the report that application of glutamate receptor antagonist obstructed the inflammatory phases of the formalin test. Based on our findings, glutamatergic system involved in the modulation of MEDS antinociception (Fig. 3 and Table 6).

In addition, recent studies have been assessed the cinnamaldehyde-induced nociception, to investigate the participation of TRPA1 receptor in the antinociceptive effect of MEDS. It has shown that cinnamaldehyde activates primary afferent sensory neurons through a direct action on TRPA1, a member of the Transient Receptor Potential family (TRP) of cation channels that are highly expressed by a subset of C-fibre nociceptors [69]. Currently, it was demonstrated that intraperitoneal administration of cinnamaldehyde, a TRPA1 agonist receptor, to mice produced a dose-dependent regular nociception [70]. Our results show that MEDS significantly reduced the cinnamaldehyde-induced pain (Fig. 3 and Table 7). This result indicates that MEDS probably interacts with the TRPA1 receptor located in $\mathrm{C}$-fibres reducing the cinnamaldehyde -induced nociception.

The present study also investigated the possible participation of cGMP pathway on the antinociceptive activity of MEDS (Fig. 5 and Table 8). Physiological functions as pain and analgesia are influenced by the cellular level of cGMP-regulated by the action of sGC interceded by nitric oxide (NO) [71]. The cGMP pathway depends on the synthesis and release of nitric oxide triggered by the activation of nitric oxide-synthase (NOS), which then activates the guanylyl synthase resulted in the formation of cGMP, the most monumental messenger of the system [72]. Therefore, cGMP seems to be very significant for the functioning of up or down regulation of nociceptor. Intracellular cGMP concentrations are regulated by the action of GCs and by the rate of degradation by cGMP-specific phosphodiesterases. It has been reported that the action of cGMP on the ion channels may be direct or through the activation of

Table 8 Effects of D. sissoo leave extract on involvement of cyclic guanosine monophosphate (cGMP) pathway

\begin{tabular}{llll}
\hline Treatment & Dose $(\mathrm{mg} / \mathrm{kg})$ & Number of writhing & Inhibition (\%) \\
\hline Control & $0.1 \mathrm{~mL} /$ mouse & $71.74 \pm 1.77$ & - \\
Methylene Blue (MB) & 20 & $58.20 \pm 2.89^{* * *}$ & 18.87 \\
MEDS + MB & $100+20$ & $37.90 \pm 0.96^{* *}$ & 47.17 \\
MEDS + MB & $200+20$ & $26.10 \pm 1.69^{* * *}$ & 63.62 \\
MEDS + MB & $400+20$ & $15.90 \pm 1.52^{* * *}$ & 77.84 \\
\hline
\end{tabular}

Values are presented as mean \pm SEM $(n=5)$. MEDS Methanolic extract of $D$. sissoo

*** $p<0.001$ compared with the control group (Dunnett's test)

** $p<0.01$ compared with the control group (Dunnett's test) 
Table 9 Effects of D. sissoo leave extract on involvement of ATP-sensitive $\mathrm{K}^{+}$channel pathway

\begin{tabular}{llcl}
\hline Treatment & Dose $(\mathrm{mg} / \mathrm{kg})$ & Number of writhing & Inhibition (\%) \\
\hline Control & $0.1 \mathrm{~mL} /$ mouse & $73.4 \pm 1.71$ & - \\
Glibenclamide (GB) & 10 & $62.3 \pm 1.11$ & 15.12 \\
MEDS + GB & $100+10$ & $42.3 \pm 2.07^{* *}$ & 42.37 \\
MEDS + GB & $200+10$ & $35.3 \pm 1.45^{* * *}$ & 51.91 \\
MEDS + GB & $400+10$ & $24.2 \pm 2.02^{* * *}$ & 67.03 \\
\hline
\end{tabular}

Values are presented as mean \pm SEM $(n=5)$. MEDS Methanolic extract of D. sissoo

*** $p<0.001$ compared with the control group (Dunnett's test)

** $p<0.01$ compared with the control group (Dunnett's test)

protein kinases and phosphodiesterases [73]. To detect the feasible involvement of cGMP in MEDS induced antinociception, methylene blue (MB), aguanylyl cyclase and/ or nitric oxide synthase inhibitor, was administered prior to inducing nociception with the intraperitoneal injection of acetic acid. The result presents that the pre-treatment with methylene blue significantly reduced the nociception caused by acetic acid and enhanced the antinociceptive effect exerted by MEDS. It has been suggested that MB promotes antinociceptive activity by inhibiting peripheral NOS and sGC, resulting in NO interference [70]. As pretreatment with $\mathrm{MB}$ and subsequent administration of MEDS at all doses increased antinociceptive effect in acetic acid-induced writhing test in mice. These results suggest that the cGMP pathways have been involved in the antinociceptive effects of the MEDS in the acetic acidinduced nociception in mice model.

The results also point out that the antinociceptive effect of MEDS might involve the participation of the ATP-sensitive $\mathrm{K}^{+}$channel pathway; glibenclamide, an ATP-sensitive $\mathrm{K}^{+}$channel antagonist, could partially reverse the antinociceptive activity of MEDS (Fig. 5 and Table 9). Previous studies report specific blockade of ATP-sensitive $\mathrm{K}^{+}$channel by glibenclamide while not affecting other types of $\mathrm{K}^{+}$channel like $\mathrm{Ca}^{2+}$ activated and voltage-gated $\mathrm{K}^{+}$channels [74, 75]. The antinociceptive action of MEDS might relate to ATP-sensitive $\mathrm{K}^{+}$channel opening and the subsequent efflux of $\mathrm{K}^{+}$ions and membrane repolarization or hyperpolarization [76].

\section{Conclusions}

It can be concluded that MEDS possesses significant antinociceptive activity in both chemical and heatinduced pain models in mice. The antinociceptive effect of MEDS is most likely mediated via inhibition of peripheral mediators and central inhibitory mechanisms. These results support the traditional use of this plant in different painful conditions. Further investigations are required to perceive the mechanisms of action of MEDS and to identify the active constituents that may be used as a lead compound for new drug development.

\section{Abbreviations}

BBB: Blood brain barrier; cGMP: Cyclic guanosine monophosphate; ICDDR, B: International Center for Diarrheal Disease and Research, Bangladesh; MEDS: Methanolic extract of D. sissoo; TRP: Transient Receptor Potential

\section{Acknowledgements}

The authors are grateful to Professor Dr. Bidyut Kanti Datta, Chairman, Department of Pharmacy, Stamford University Bangladesh for his permission to use the facilities of the Pharmacology and Phytochemistry Laboratory.

\section{Funding}

This research work did not have any particular funding. All the studies had been self-funded by author and co-authors.

\section{Availability of data and materials}

The datasets supporting the conclusions of this article are included within the article and its supplementary files.

\section{Authors' contributions}

MAM designed and coordinated all laboratory experiments, analyzed and interpreted results. MFHK and MAM conducted all experiments. AK and MAM did statistical analysis and drafted the manuscript. All authors read and approved the final manuscript.

\section{Competing interests}

The authors alone are responsible for the content and writing of the paper. The authors declare that they have no competing interests.

\section{Consent for publication}

Not applicable.

\section{Ethics approval and consent to participate}

The manuscript does not contain any individual person's data in any form. So, this information is not relevant.

All the experimental mice were treated following the Ethical Principles and Guidelines for Scientific Experiments on Animals (1995) formulated by The Swiss Academy of Medical Sciences and the Swiss Academy of Sciences. The Institutional Animal Ethical Committee (SUB/IAEC/16.01) of Stamford University Bangladesh approved all experimental rules.

Received: 29 September 2016 Accepted: 6 January 2017 Published online: 23 January 2017

\section{References}

1. Al-Quran S. Taxonomical and pharmacological survey of therapeutic plants in Jordan. J Nat Prod. 2008;1:10-26.

2. Shah MH, Mukhtar I, Khan SN. Medicinal importance and association of pathological constraints with Dalbergia sissoo. Pak J Phytopathol. 2010;22:135-8.

3. Hussain K, Shahazad A, Zia-ul-Hussnain S. An ethnobotanical survey of important wild medicinal plants of Hattar District Haripur, Pakistan. Ethnobot Leaflets. 2008;12:29-35.

4. Yadav H, Yadav M, Jain S, Bhardwaj A, Singh V, Parkash O, Marotta F. Antimicrobial property of a herbal preparation containing Dalbergia sissoo and Datura tramonium with cow urine against pathogenic bacteria. Int J Immunopathol Pharmacol. 2008;21:1013-20.

5. Kirtikar KR, Basu BD. Indian medicinal plants. 2nd ed. Allahabad: Lalit Mohan Basu; 1933. p. 818-900.

6. Sharma PC, Yelne MB, Dennis TJ. Database on medicinal plants used in ayurveda, vol. 2. New Delhi: Central Council for Research in Ayurveda and Siddha; 2001. p. 481-90.

7. Ishtiaq MC, Khan MA, Hanif W. Ethno veterinary medicinal uses of plants from Samahni Valley Dist. Bhimber, (Azad Kashmir). Pak J Plant Sci. 2006;5:390-6.

8. Ahmad H. Issues regarding medicinal plants of Pakistan. Udyana Today. 2005;6:6-7.

9. Chunekar KC, Pandey GS. Bhavprakash Nighantu of Shri Bhavamisra Varanasi. Indian Materia Medica. India: Chaukhambha Bharati Academy; 1999. p. 105.

10. Sultana S, Khan MA, Ahmad M, Zafar M. Indigenous knowledge of folk herbal medicines by the women of district Chakwal, Pakistan. Ethnobot Leaflets. 2006;10:243-53. 
11. Sarg T, Ateva AM, Ghani AA, Badr W, Shams G. Phytochemical and Pharmacological studies of Dalbergia sissoo growing in Egypt. Pharm Biol. 1999:37:54-62.

12. Mukerjee SK, Saroja T, Seshadri TR. Dalbergichromene, a new neoflavonoid from stem-bark and heartwood of Dalbergia sissoo. Tetrahedron. 1971;27:799-803.

13. Sharma A, Chibber SS, Chawla HM. Caviunin 7-O-gentiobioside from Dalbergia sissoo pods. Phytochem. 1979;18:1253.

14. Sharma A, Chibber SS, Chawal HM. Isocaviunin 7- gentiobioside, a new isoflavone glycoside from Dalbergia sissoo. Phytochem. 1980;19:715.

15. Ramireddy V, Reddy NP, Khalivulla SI, Mopuru V, Reddy B, Gunasekar D, Blond A, Bodo B. O-prenylated flavonoids from Dalbergia sissoo. Phytochem. 2008;1:23-6.

16. Vikas R, Vineet K, Soni PL. Structure of the oligosaccharides isolated from Dalbergia sissoo Roxb. Leaf polysaccharide. Carbohydr Polym. 2009;78:520-5.

17. Folk Medicine. The Folk Medicines Used In The Province of Sindh, Pakistan, Moringa rivae (Chiovenda). International Center for Chemical and Biological Sciences. 2010. p. 28

18. Zhou J, Xie G, Yan X. Encyclopedia of Traditional Chinese Medicines -Molecular Structures, edition 1st. Berlin Heidelberg: Springer -Verlag; 2011.

19. Hajare SW, Suresh C, Tandan SK, Sarma J, Lal J, Telang AG. Analgesic and antipyretic activities of Dalbergia sissoo leaves. Indian J Pharmacol. 2000;32:357-60.

20. Niranjani PS, Singh S, Prajapati K, Jain SK. Antidiabetic activity of ethanolic extract of Dalbergis sissoo L. Leaves in alloxan-induced diabetic rats. Int J Current Pharm Res. 2010;2:24-7.

21. Kumar SM. Anti-inflammatory activity of root of Dalbergia sissoo (Rox.b) in carrageenan-induced paw edema in rats. Pharmacognosy J. 2010;2:427-39.

22. Brijezh S, Dazwanl PG, Tetall P, Antla NH, Birdi TJ. Studies on Dalbergia sissoo(Roxb) leaves: possible mechanism(s) of action in infectious diarrhoea. Indian J Pharmacol. 2006;38:120-4.

23. Mohammad A, Arun K. Phytochemical investigation and evaluation of antinociceptive activity of ethanolic extract of Dalbergia sissoo (Roxb.) bark. J Nat Sci Biol Med. 2011:2:76-9.

24. Nayan R, Rajibul AL, Ismail SK, Deepa K, Ghosh T, Begum NA. A detailed study on the antioxidant activity of the stem bark of Dalbergia sissoo Roxb, an Indian medicinal plant. Food Chem. 2011;126:1115-21.

25. Neeru V, Manisha V. Antispermatogenic activity of ethanol extract of Dalbergia sissoo Roxb. stem bark. J Acupunct Meridian Stud. 2011;4:116-22.

26. Ansari MA, Razdan RK, Tandon M, Padma V. Larvicidal and repellent action of Dalbergia sissoo Roxb. oil (F.Leguminosae) oil against mosquitoes. Bio Resour Technol. 2000;73:207-11.

27. Dixit P, Chillara R, Khedgikar V, Gautam J, Kushwaha P, Kumar A, Singh D, Trivedi R, Maurya R. Constituents of Dalbergia sissoo Roxb. leaves with osteogenic activity. Bioorg Med Chem Lett. 2012;22(2):890-7.

28. Kharkwal $H$, Kharkwal A, Panthari P, Kharkwal H. Anti-termite activity of heartwood of Dalbergia sissoo Roxb. Ex.Dc. World J Phar Pharma Scis. 2014;3(6):673-9.

29. Hugar MH, Hosamani KM, Ahmed L. Phytochemical and pharmacological studies of ethanol extract of Dalbergia sissoo seeds. An approach for the invivo analgesic and antipyretic activities. Int J Pharm Bio Sci. 2010;1(4):272-80.

30. Nk U. Evaluation of anthelmintic activity of Dalbergia sissoo roxb. Int J Pharm Sci Res. 2011;2(1):171-4.

31. Adenusi AA, Odaibo AA. Laboratory assessment of molluscicidal activity of crude aqueous and ethanolic extracts of Dalbergia sissoo plant parts against Biomphalaria pfeifferi. Travel Med Infec Dis. 2008;6(4):219-27.

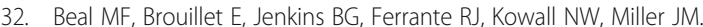
Neurochemical and histological characterization of striatal excitotoxic lesions produced by the mitochondrial toxin 3- nitropropionic acid. J Neurosci. 1993;13:4181-92.

33. Madhava CK, Sivaji K, Tulasi RK. Flowering plants of chittoor district Andhra Pradesh, India. Tirupati: Students Offset Printers; 2008. p. 88.

34. Ghosh MN. Fundamental of experimental pharmacology. 3rd ed. Mumbai: Hilton and Company; 2005

35. Ghani A. Medicinal plants of Bangladesh with chemical constituents and uses. 2nd ed. Dhaka: Asiatic Society of Bangladesh; 2003. p. 274

36. Eddy NB, Leimbach D. Synthetic analgesics:Il. Dithienylbutenyl and dithienylbutylamines. J Pharmacol Exp Ther. 1953;107:385-93.

37. D Amour FE, Smith DL. A method for determining loss of pain sensation. Pharmacol Exp Ther. 1941;72:74-9.

38. Sulaiman MR, Mohamad TAT, Mossadek WMS, Moin S, Yusof M, Mokhtar AF, Zakaria ZA, Israf DA, Lajis N. Antinociceptive activity of the essential oil of Zingiber zerumbet. Planta Med. 2010;76:107-12.
39. Santos ARS, Calixto JB. Further evidence for the involvement of tachykinin receptor subtypes in formalin and capsaicin models of pain in mice. Neuropeptides. 1997;31:381-9.

40. Santos ARS, Miguel OG, Yunes RA, Calixto JB. Antinociceptive properties of the new alkaloid, cis-8,10-di-N-propyllobelidiol hydrochloride dihydrate isolated from Siphocampylus verticillatus: evidence for the mechanism of action. J Pharmacol Exp Ther. 1999;289:417-26.

41. Beirith A, Santos AR, Calixto JB. Mechanisms underlying the nociception and paw oedema caused by injection of glutamate into the mouse paw. Brain Res. 2002;924:219-28.

42. Andrade EL, Luiz AP, Ferreira J, Calixto JB. Pronociceptive responce elicited by TRPA1 receptor activation in mice. Neuroscience. 2008;152:511-20.

43. Khan H, Saeed M, Gilani AUH, Khan MA, Khan I, Ashraf N. Anti- nociceptive activity of aerial parts of Polygonatum verticillatum: attenuation of both peripheral and central pain mediators. Phytother Res. 2011:25:1024-30.

44. Abacioglu N, Tunctan B, Akbulut E, Cakici I. Participation of the components of I-arginine/nitric oxide/cGMP cascade by chemically-induced abdominal constriction in the mouse. Life Sci. 2000;67:1127-37.

45. Perimal EK, Akhtar MN, Mohamad AS, Khalid MH, Ming OH, Khalid S, Tatt LM, Kamaldin MN, Zakaria ZA, Israf DA, Lajis N, Sulaiman MR. Zerumbone-induced antinociception: involvement of the l-argininenitric oxide-cGMP-PKC-K+ ATP channel pathways. Basic Clin Pharmacol Toxicol. 2011;108:155-62.

46. Mohamad AS, Akhtar MN, Khalivulla SI, Perimal EK, Khalid MH, Ong HM, Zareen S, Akira A, Israf DA, Lajis N, Sulaiman MR. Possible participation of nitric oxide/cyclic guanosine monophosphate/protein kinase C/ATPsensitive $\mathrm{K}(+)$ channels pathway in the systemic antinociception of Flavokawin. 2011.

47. Srinivasan K, Muruganandan S, Lal J, Chandra S, Tandan SK, Raviprakash V, Kumar D. Antinociceptive and antipyretic activities of Pongamia pinnata leaves. Phytother Res. 2003;17:259-64.

48. Arslan R, Bektas N. Antinociceptive effect of methanol extract of Capparis ovata in mice. Pharm Biol. 2010:48:1185-90.

49. Jinsmaa Y, Fujitab Y, Shiotanib K, Miyazakic A, Lib T, Tsuda Y, Okada Y, Amboe A, Sasakie Y, Bryanta SD, Lawrence H, Lazarus LH. Differentiation of opioid receptor preference by [Dmt1]endomorphin-2-mediated antinociception in the mouse. Eur J Pharmacol. 2005:509:37-42.

50. Trongsakul S, Panthong A, Kanjanapothi D, Taesotikul T. The analgesic, antipyretic and anti-inflammatory activity of Diospyros variegata Kruz. J Ethnopharmacol. 2003;85:221-5.

51. Bentley GA, Newton SH, Starr J. Studies on the antinociceptive action of agonist drugs and their interaction with opioid mechanisms. $\mathrm{Br} J$ Pharmacol. 1983;79:125.

52. Ikeda Y, Ueno A, Naraba H, Ohishi S. Involvement of vanilloid receptor VR and prostanoids in the acid acid-induced writhing responses of mice. Life Sci. 2001:69:2911-9.

53. Radu BM, Bramanti P, Osculati F, Flonta ML, Radu M, Bertini G, Fabene PF. Neurovascular unit in chronic pain. Mediat Inflamm. 2013:64:826-8.

54. Anosike CA, Obidoa O, Ezeanyika LUS. Membrane stabilization as a mechanism of the anti-inflammatory activity of methanol extract of garden egg (Solanum aethiopicum). DARU J Pharma Sci. 2012;20:76.

55. Andrade SF, Cardoso LGV, Carvalho JCT, Bastos JK. Anti-inflammatory and antinociceptive activities of extract, fractions and populnoic acid from bark wood of Austroplenckia populnea. J Ethnopharmacol. 2007:109:464-71.

56. Tjølsen A, Berge OG, Hunskaar S, Rosland JH, Hole K. The formalin test: an evaluation of the method. Pain. 1992:51:5-17.

57. Oku H, Ishiguro K. Cyclooxygenase-2 inhibitory 1,4-naphthoquinones from impatiens balsamina. Bio Pharma Bull. 2002;25:658-60.

58. Kempuraj D, Madhappan B, Christodoulou S, Boucher W, Cao J, Papadopoulou N, Cetrulo CL, Theoharides TC. Flavonols inhibit proinflammatory mediator release, intracellular calcium ion levels and protein kinase C theta phosphorylation in human must cells. B J Pharmacol. 2005:145:934-44.

59. Annegowda HV, Nee CW, Mordi MN, Ramanathan S, Mansor SM. Evaluation of phenolic content and antioxidant property of hydrolysed extract of Terminalia catappa L. leaf. Asian J Plant Sci. 2010;9:479-85.

60. Ramesh M, Rao YN, Rao AVNA, Prabhakar MC, Rao CS, Muralidhar N, Reddy BM. Antinociceptive and anti-inflammatory activity of a flavonoid isolated from Caralluma attenuate. J Ethnopharmacol. 1998;62:63-6.

61. Jothimanivannan C, Kumar RS, Subramanian N. Anti-inflammatory and analgesic activities of ethanol extract of aerial parts of Justicia gendarussa Burm. Int J Pharmacol. 2010;6:278-83. 
62. Ramprasath VR, Shanthi P, Sachdanandam P. Immunomodulatory and antiinflammatory effects of Semecarpus anacardium Linn. Nut milk extract in experimental inflammatory conditions. Biol Pharm Bull. 2006;29:693-700.

63. Mao J, Price DD, Hayes RL, Lu J, Mayer DJ. Differential roles of NMDA and non-NMDA receptor activation in induction and maintenance of thermal hyperalgesia in rats with painful peripheral mononeuropathy. Brain Res. 1992;598:271-8.

64. Aanonsen LM, Lei S, Wilcox GL. Excitatory amino acid receptors and nociceptive neurotransmission in rat spinal cord. Pain. 1990;41:309-21.

65. Fundytus ME. Glutamate receptors and nociception: implications for the drug treatment of pain. CNS Drugs. 2001;15:29-58.

66. Dickenson AH, Sullivan AF. Evidence for a role of the NMDA receptor in the frequency dependent potentiation of deep rat dorsal horn nociceptive neurones following C fibre stimulation. Neuropharmacology. 1987;26:1235-8.

67. Davies SN, Lodge D. Evidence for involvement of N-methylaspartate receptors in "wind-up" of class 2 neurones in the dorsal horn of the rat. Brain Res. 1987:424:402-6.

68. Neugebauer V. Metabotropic glutamate receptors-important modulators of nociception and pain behavior. Pain. 2002;98:1-8.

69. McNamara RC, Mandel-Brehm J, Bautista DM, Siemens J, Deranian KL, Zhao M. TRPA1 mediates formalin-induced pain. Proc Natl Acad Sci U S A. 2007:104:525-30.

70. Abacioğlu N, Tunctan B, Akbulut E, Cakici I. Participation of the components of L-arginine/nitric oxide/cGMP cascade by chemically-induced abdominal constriction in the mouse. Life Sci. 2000;67:1127-37.

71. De Moura S. Role of the NO-cGMP pathway in the systemic antinociceptive effect of clonidine in rats and mice. Pharmacol Biochem Behav. 2004;78:247-53

72. Jain NK, Patil CS, Singh A, Kulkarni SK. Sildenafil-induced peripheral analgesia and activation of the nitric oxide-cyclic GMP pathway. Brain Res. 2001;909:170-80

73. Xu JY, Pieper GM, Tseng LF. Activation of a NO-cyclic GMP system by NO donors potentiates beta-endorphin-induced antinociception in the mouse. Pain. 1995;63:377-83.

74. Alves D, Duarte I. Involvement of ATP-sensitive $\mathrm{K}^{+}$channels in the peripheral antinociceptive effect induced by dipyrone. Eur J Pharmacol. 2002:444:47-52

75. Jesse CR, Savegnago L, Nogueira CW. Role of nitric oxide/cyclic GMP/K $\mathrm{K}^{+}$ channel pathways in the antinociceptive effect caused by2, 3-bis (mesitylseleno) propenol. Life Sci. 2007:81:1694-702.

76. Lawson K. Potassium channel activation: a potential therapeutic approach. Pharmacol Ther. 1996;70:39-63.

\section{Submit your next manuscript to BioMed Central and we will help you at every step:}

- We accept pre-submission inquiries

- Our selector tool helps you to find the most relevant journal

- We provide round the clock customer support

- Convenient online submission

- Thorough peer review

- Inclusion in PubMed and all major indexing services

- Maximum visibility for your research

Submit your manuscript at www.biomedcentral.com/submit 